University of Nebraska - Lincoln

DigitalCommons@University of Nebraska - Lincoln

\title{
Evaluation of Nitrate Nitrogen Fluxes from a Tile-Drained Watershed in Central lowa
}

\author{
M. D. Tomer \\ USDA-ARS National Soil Tilth Laboratory, tomer@nstl.gov \\ D. W. Meek \\ USDA-ARS National Soil Tilth Laboratory \\ D. B. Jaynes \\ USDA-ARS National Soil Tilth Laboratory \\ J. L. Hatfield \\ USDA-ARS National Soil Tilth Laboratory, jerry.hatfield@ars.usda.gov
}

Follow this and additional works at: https://digitalcommons.unl.edu/usdaarsfacpub

Tomer, M. D.; Meek, D. W.; Jaynes, D. B.; and Hatfield, J. L., "Evaluation of Nitrate Nitrogen Fluxes from a Tile-Drained Watershed in Central lowa" (2003). Publications from USDA-ARS / UNL Faculty. 1360. https://digitalcommons.unl.edu/usdaarsfacpub/1360

This Article is brought to you for free and open access by the U.S. Department of Agriculture: Agricultural Research Service, Lincoln, Nebraska at DigitalCommons@University of Nebraska - Lincoln. It has been accepted for inclusion in Publications from USDA-ARS / UNL Faculty by an authorized administrator of DigitalCommons@University of Nebraska - Lincoln. 


\title{
Evaluation of Nitrate Nitrogen Fluxes from a Tile-Drained Watershed in Central Iowa
}

\author{
M. D. Tomer,* D. W. Meek, D. B. Jaynes, and J. L. Hatfield
}

\begin{abstract}
Nitrate $\mathrm{N}$ fluxes from tile-drained watersheds have been implicated in water quality studies of the Mississippi River basin, but actual $\mathrm{NO}_{3}-\mathrm{N}$ loads from small watersheds during long periods are poorly documented. We evaluated discharge and $\mathrm{NO}_{3}-\mathrm{N}$ fluxes passing the outlet of an Iowa watershed (5134 ha) and two of its tile-drained subbasins (493 and $863 \mathrm{ha}$ ) from mid-1992 through 2000. The cumulative $\mathrm{NO}_{3}-\mathrm{N}$ load from the catchment was $168 \mathrm{~kg} \mathrm{ha}^{-1}$, and 176 and $229 \mathrm{~kg} \mathrm{ha}^{-1}$ from the subbasins. The outlet had greater total discharge $(1831 \mathrm{~mm})$ and smaller flow-weighted mean $\mathrm{NO}_{3}-\mathrm{N}$ concentration $\left(9.2 \mathrm{mg} \mathrm{L}^{-1}\right.$ ) than the subbasins, while the larger subbasin had greater discharge (1712 vs. $1559 \mathrm{~mm})$ and mean $\mathrm{NO}_{3}-\mathrm{N}$ concentration (13.4 vs. $11.3 \mathrm{mg} \mathrm{L}^{-1}$ ) than the smaller subbasin. Concentrations exceeding $10 \mathrm{mg} \mathrm{L}^{-1}$ were common, but least frequent at the outlet. Nitrate $\mathbf{N}$ was generally not diluted by large flows, except during 1993 flooding. The outlet showed smaller $\mathrm{NO}_{3}-\mathrm{N}$ concentrations at low flows. Relationships between discharge and $\mathrm{NO}_{3}-\mathrm{N}$ flux showed log-log slopes near 1.0 for the subbasins, and 1.2 for the outlet, considering autocorrelation and measurement-error effects. We estimated denitrification of subbasin $\mathrm{NO}_{3}-\mathrm{N}$ fluxes in a hypothetical wetland using published data. Assuming that temperature and $\mathrm{NO}_{3}-\mathrm{N}$ supply could limit denitrification, then about $20 \%$ of the $\mathrm{NO}_{3}-\mathrm{N}$ would have been denitrified by a wetland constructed to meet USDA-approved criteria. The low efficiency results from the seasonal timing and $\mathrm{NO}_{3}-\mathrm{N}$ content of large flows. Therefore, agricultural and wetland best management practices (BMPs) are needed to achieve water quality goals in tiledrained watersheds.
\end{abstract}

$\mathrm{I}$ NTENSIVELY CROPPED WATERSHEDS of the U.S. Midwest have been identified as important sources of nutrients within the Mississippi River basin that contribute to hypoxic conditions in the Gulf of Mexico (Burkart and James, 1999). Midwestern watersheds have been artificially drained to a large extent, with drainage ditches and subsurface tile lines widely installed during the last 150 years to allow settlement and agricultural use of the land (McCorvie and Lant, 1993). Before settlement, wetlands were a key feature of the Midwestern landscape, due to a dominant influence of slowly drained soils derived from fine-textured glacial deposits (Eidem et al., 1999; Ruhe, 1969; Rodvang and Simpkins, 2001). In this setting, today's agricultural systems would largely be infeasible without artificial drainage. However, nutrient flows from these drainage systems have emerged as a key to the management of water quality in the Mississippi River basin (Randall and Gross, 2001).

Interactions between agricultural practices, watershed dynamics, water quality, and the health of aquatic and marine ecosystems are complex. Recent research has focused on understanding the dynamics of nutrient

USDA Agricultural Research Service-National Soil Tilth Laboratory, 2150 Pammel Drive, Ames, IA 50010. Received 15 Apr. 2002. *Corresponding author (tomer@nstl.gov).

Published in J. Environ. Qual. 32:642-653 (2003). fluxes in agricultural watersheds (Alexander et al., 1996, 2000; Burkart and James, 1999; David and Gentry, 2000; Pionke et al., 1999; Sauer et al., 2001), on understanding how management practices can affect fluxes through tile lines (Bjorneberg et al., 1998; Bolton et al., 1970; Dinnes et al., 2002; Randall and Gross, 2001), and on ecosystem responses to nutrient loading (Lowery, 1998; Mallin et al., 2001). These kinds of improvements in watershed science require that we better understand the dynamics of nutrient fluxes, and not just concentrations. Policies being developed under the U.S. Clean Water Act of 1972, Section 303(d), are focused on the total maximum daily load (TMDL) that a given water body can accept without impairing its use or ecological function. Therefore, water quality monitoring efforts are increasingly aimed at obtaining both water flow and contaminant concentration data, as both are required to calculate nutrient fluxes and total loads.

Despite the importance of tile drainage and our need to understand nutrient flux dynamics in Midwestern watersheds, there are few long-term data sets that summarize nutrient fluxes from tile-drained watersheds in this region. This is problematic because a long-term record that captures a wide range of hydrologic conditions provides the best opportunity to interpret water quality data. But succinct interpretation of water quality records can be difficult because, in effect, watershed processes uncouple hydrologic flows and solute fluxes. The complexities of water-flow pathways and the timing of their responses to rainfall control a watershed's solute fluxes, even for a conservative solute delivered solely via rainfall (Kirchner et al., 2000). Biogeochemical processes and land management also cause variations in nutrient fluxes, and the sum effect is great variation in hydrologic and nutrient fluxes across the years. Few, if any, watershed monitoring research projects have the opportunity and resources to characterize all the interacting processes affecting these variations at the watershed scale. Here we aim to use simple tools to evaluate key attributes of water flows and nutrient fluxes in a way that captures watershed performance. In small watersheds at least, this may indicate key processes that are occurring, and provide ways to better understand the opportunities and challenges to manage nutrient flows.

As part of the Management Systems Evaluation Area program (Onstad et al., 1991), hydrologic flows and nitrate concentrations have been monitored within the Walnut Creek watershed of central Iowa since 1992 (Hatfield et al., 1999), providing the opportunity to summarize nutrient flows from a tile-drained watershed over a significant time frame. The objectives of this paper include:

Abbreviations: DOY, sequential day of year. 
Objective 1: Summarize hydrologic discharge and $\mathrm{NO}_{3}-\mathrm{N}$ transport from Walnut Creek watershed and two of its subbasins that are delineated by subsurface drainage systems.

Objective 2: Evaluate the relationships between water flows and $\mathrm{NO}_{3}-\mathrm{N}$ fluxes at these three locations

Objective 3: Estimate what reductions in $\mathrm{NO}_{3}-\mathrm{N}$ fluxes could occur via denitrification if constructed wetlands had been installed to intercept these flows.

\section{THE WALNUT CREEK WATERSHED}

Measurements of flow and water quality were gathered at Walnut Creek in central Iowa between 1992 and 2000. The monitoring program was initiated in 1991 under the Management Systems Evaluation Area program (Onstad et al., 1991). The catchment is dominated by recent, fine-textured, and poorly drained glacial soils of the Des Moines lobe that are usually classified (Soil Survey Staff, 1994) as Hapludolls or Haplaquolls (Hatfield et al., 1999). Stream drainage networks have not fully developed across the undulating terrain, and therefore artificial drainage has been widely installed to allow for agricultural production, which is dominantly (approximately $85 \%$ ) under a corn (Zea mays L.) and soybean [Glycine max (L.) Merr.] rotation. The soils, physiography, and agricultural practices within the watershed are fully described by Hatfield et al. (1999). Eidem et al. (1999) describe the geologic setting, and Jaynes et al. (1999) summarize hydrologic and contaminant data collected between 1992 and 1995.

The artificial drainage system consists of ditches, subsurface pipes and tile lines, and surface water intakes. Surface water intakes are located within closed depressions and along roadside ditches. These intakes, along with subsurface tile lines installed in varying patterns across the cropped fields, deliver water to drainage mains, which are maintained by local (county) authorities. The drainage mains deliver water to ditches (maintained by the same authorities), which in turn drain to local streams. Installation of these systems at Walnut Creek began nearly 100 years ago, with maintenance and expansion continuing through current times by both local authorities and private landowners. As a result, the subsurface systems are not consistently mapped, and, in essence, impossible to fully characterize by currently available technology.

Fertilizer management practices can affect the loss of $\mathrm{NO}_{3}-\mathrm{N}$ from subsurface drainage systems (Randall and Gross, 2001). In the Walnut Creek watershed, applications of fertilizer nitrogen, at rates averaging about 150 $\mathrm{kg} \mathrm{N} \mathrm{ha}{ }^{-1}$, are frequently applied in the autumn to fields that will be planted to corn the following spring (Hatfield et al., 1999). This is done to ease difficulties in scheduling springtime farming operations that result from wet weather conditions. But the relatively high rates of fertilizer application and asynchronous timing with crop uptake may result in significant leaching of $\mathrm{NO}_{3}-\mathrm{N}$. Dinnes et al. (2002) give a comprehensive discussion of $\mathrm{N}$ fertilizer management in tile-drained areas. Tiles provide short-circuiting pathways for delivery of shallow soil water and runoff waters to streams, which may minimize opportunities for riparian-zone processes (e.g., biological uptake and denitrification) to reduce $\mathrm{NO}_{3}-\mathrm{N}$ concentrations.

Given these concerns, the Walnut Creek project was initiated to characterize the hydrology of a tile-drained Midwestern landscape, and its accompanying dynamics of $\mathrm{NO}_{3}-\mathrm{N}$ and pesticide fluxes. To date, monitoring has provided a long-term data set (approximately nine years) of flow quantities and water quality at the watershed outlet (draining $5130 \mathrm{ha}$ ), and from several subbasins defined by subsurface drainage networks (Fig. 1). County map archives provide reliable information on the location of main drainage lines and associated subbasin areas. The data considered here were collected at three locations, referred to as the 210-tile site, a subbasin draining $493 \mathrm{ha}$; the 230-tile site, a subbasin draining $863 \mathrm{ha}$; and the 330-stream site, located at the watershed's outlet (Fig. 1).

\section{METHODS}

\section{Data Collection and Processing}

Jaynes et al. (1999) described data collection equipment and procedures in detail. Briefly, flow from the watershed outlet (330-stream site) was measured with a stage-discharge relationship (Rantz, 1982). Water stage was measured using a pressure transducer and recorded every $5 \mathrm{~min}$. A weir was installed to provide low-flow control, and channel characteristics were used with Mannings equation to calculate large flows that submerged the weir. Discharge from the main pipes for the tile subbasins was accomplished with a combination depthvelocity meter designed for measuring pipe flows. Depth and velocity were recorded every $5 \mathrm{~min}$.

Tipping-bucket rain gauges located in the catchment and its subbasins recorded precipitation, also at 5-min intervals. Cumulative precipitation figures included daily snowfall data collected at the Ames (IA) waste treatment plant, about 1.5 $\mathrm{km}$ north of the 330-stream site, and outside the watershed.

Water samples were collected using both grab methods, usually at weekly intervals, and by automatic sampling at all three locations. Auto sampling was activated by a change in stage height, or when three days had elapsed since the previous sampling. Water samples were analyzed for nitrate concentration with an autoanalyzer method, as summarized by Hatfield et al. (1999) and detailed by Hatfield and Sauer (1994). The method had a detection limit of $1 \mathrm{mg} \mathrm{L}^{-1}$ for $\mathrm{NO}_{3}-\mathrm{N}$ concentration.

The flow data were averaged for 30-min periods, and these averages were used in further calculations. The three flowmonitoring stations were all operational as of 18 July 1992, and measurements from then through the year 2000 were included in the analysis. However, frozen conditions during winter prevented reliable operation of the pressure transducers, and therefore much of the record during winter months and spring thaw was omitted. Under ice-free conditions, there were some periods when not all sensors were functioning. These missing data were estimated using relationships with other nearby stations included in the study (Jaynes et al., 1999). Missing tile flows were usually estimated using flows from other tile mains, and missing outlet flows were estimated using flows from an upstream gauging station (Site 310, shown in Fig. 1). Data were plotted, preferably using times near the gap in data, and best-fit expressions were determined. These 


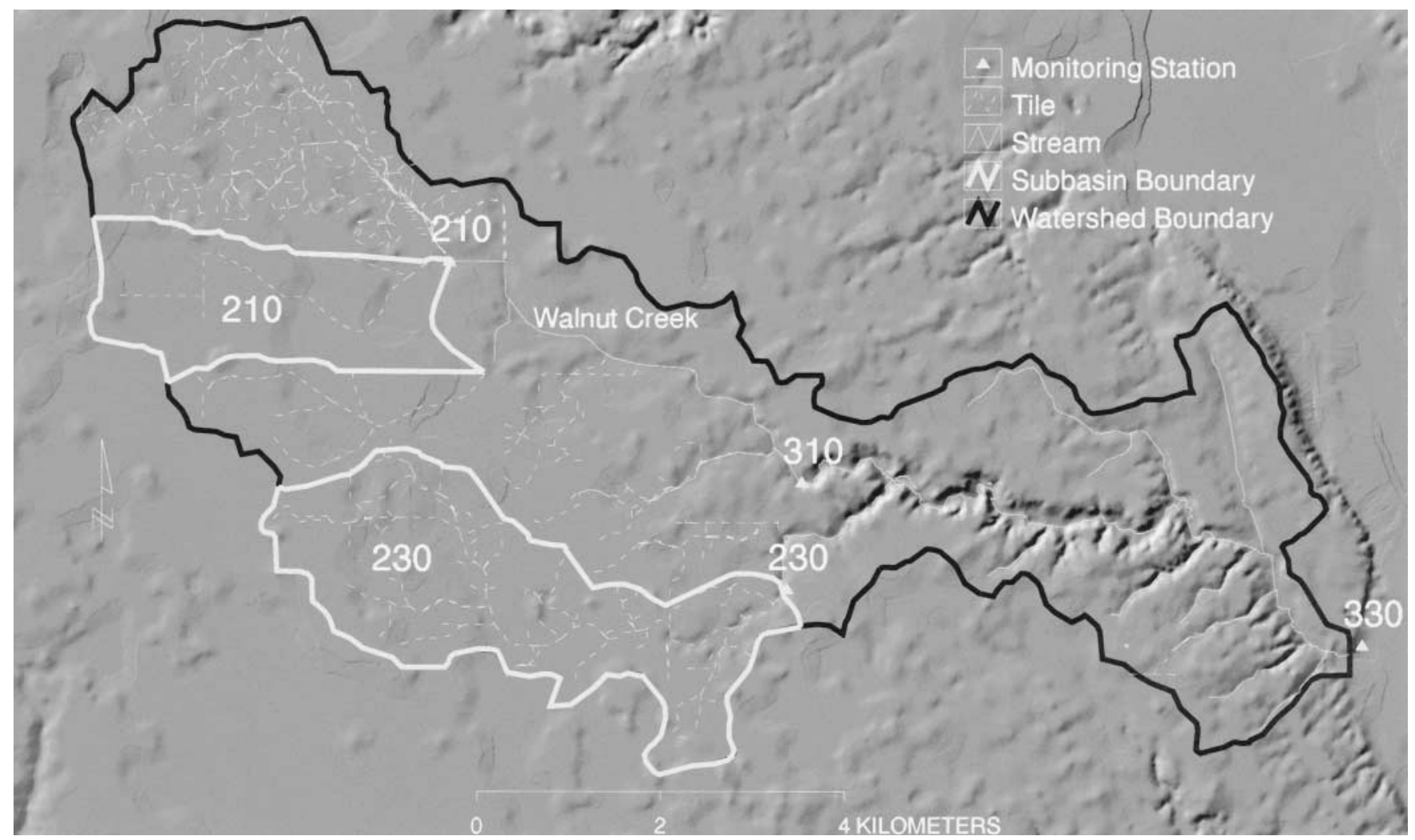

Fig. 1. Map of Walnut Creek watershed showing monitoring locations for the watershed (330-stream site), two tile-drained subbasins (210- and 230-tile sites), the stream network, and known locations of tile mains. The 310-stream site, which provided data for flow calibrations (see text), is also shown.

expressions were most often linear, but in some instances were polynomial, or exponential (as in Jaynes et al., 1999). Correlation coefficients $(r)$ usually exceeded 0.9 , with a few minor exceptions. These data gaps were brief (less than three weeks), except for a 190-d gap in the record for the 230-tile site that ended in July 1998. Most of this gap was filled using an exponential relation with the 210-tile site data. But there was also about $18 \mathrm{~d}$ of large flows, during which this exponential relation could not reasonably be extrapolated. These 230tile site flows were estimated using a polynomial expression with the 210-tile site obtained from high flow conditions in 1993.

Measured concentrations of $\mathrm{NO}_{3}-\mathrm{N}$ were multiplied by discharge to obtain estimates of $\mathrm{N}$ fluxes. For each discrete sampling time, a time interval was assigned that went from the midpoint time since the previous sample was collected to the midpoint time before the subsequent sample was collected. Flows during each time interval were accumulated and multiplied by $\mathrm{NO}_{3}-\mathrm{N}$ concentration to obtain a mass flux. Average fluxes of water and $\mathrm{NO}_{3}-\mathrm{N}$ were finally calculated, and expressed as $\mathrm{mm} \mathrm{h}^{-1}$ for water flux, and $\mathrm{kg} \mathrm{ha}^{-1} \mathrm{~d}^{-1}$ for $\mathrm{NO}_{3}-\mathrm{N}$, to provide a unit-area comparison between sites. Samples collected during frozen stream conditions or early spring thaw were omitted from these calculations.

\section{Data Summarization}

Precipitation $(\mathrm{mm})$, flow $\left(\mathrm{mm} \mathrm{h}^{-1}\right)$, and $\mathrm{NO}_{3}-\mathrm{N}$ load $(\mathrm{kg}$ $\mathrm{ha}^{-1}$ ) were summed, and flow-weighted $\mathrm{NO}_{3}-\mathrm{N}$ concentrations calculated, for each calendar year. We then summarized the flow, $\mathrm{NO}_{3}-\mathrm{N}$ concentration, and $\mathrm{NO}_{3}-\mathrm{N}$ flux data by plotting duration curves and calculating univariate statistics for each monitoring station. Duration curves were plotted using the individual event data. In doing so, we extended the concept of flow-duration curves, which hydrologists use to characterize variations in stream flow records (Prakash et al., 1996), to also plot duration curves for nitrate concentration and flux. The entire sample record was then sorted according to sampling date and summed by date; these date-sorted totals were plotted to examine the seasonality of the data.

Univariate statistics were calculated on weekly averaged data, which provided equal weighting of observations. The weekly interval was selected because it was the largest interval between samples. We calculated product-moment statistics of mean, standard deviation, skewness, and kurtosis.

\section{Data Analyses: Flow-Nitrate Nitrogen Flux Relationships}

In this evaluation, we used a simple expression to summarize the flow $-\mathrm{NO}_{3}-\mathrm{N}$ flux relationships for these three monitoring stations, as follows. If water flow $\left(Q, \mathrm{~mm} \mathrm{~h}^{-1}\right)$ is plotted against flux of a given solute $\left(L, \mathrm{~kg} \mathrm{ha}^{-1} \mathrm{~d}^{-1}\right)$ on a $\log -\log$ plot, then a line fitted to this plot is given by:

$$
L=a Q^{b}
$$

If the concentration of the solute never changes in the record, all points would plot exactly on a straight line with a slope $(b)$ of 1 , and the intercept's value $(a)$ would be determined by the concentration (and unit-conversion constants). Of course, water quality data do not behave this way; concentrations often change in a way that partly depends on $Q$. Large flows may flush contaminants and exhibit an increased concentration, and/or in-stream processes may more effectively remove contaminants at low flows. Under these scenarios the slope's value $(b)$ would exceed 1 . In other locations, 
or under a different land use, large flows may lead to diluted concentrations, leading to $b<1$. Minimal values of $b$ would be associated with those constituents associated with baseflow contribution to stream flow.

The term $b$ in Eq. [1] was named the elasticity coefficient by Alexander et al. (1996), in a study of annual flows and $\mathrm{N}$ loads discharged from U.S. rivers to the Atlantic Ocean. Among these rivers, values of $b$ ranged from 0.05 to 1.59 , with a median of 0.93 . Annual data for developed watersheds of the USA show an elasticity coefficient of 0.86 (Sauer et al., 2001), suggesting smaller $N$ concentrations in basins yielding more flow. Here we apply this concept to detailed data from three single stations, undertaking statistical procedures to account for measurement errors and autocorrelation, described as follows.

Coefficients for Eq. [1] were determined for a summary data set that was calculated to reduce autocorrelation effects. To obtain this summary data set, the discharge and $\mathrm{NO}_{3}-\mathrm{N}$ flux data were first averaged across 7 -d periods, and then evaluated to determine the time interval (number of weeks) at which flows became independent. This is known as the scale of fluctuation, or correlation scale (Vanmarcke, 1983; Cressie, 1993), which is denoted as $\theta$ and defined as:

$$
\theta=2 \int_{0}^{\infty} \rho(m) d m
$$

In Eq. [2], $m$ is the time interval separating a pair of observations, and $\rho(m)$ is the autocorrelation function (Vanmarcke, 1983; Cressie, 1993) defined as:

$$
\begin{aligned}
\rho(m)= & \operatorname{covariance}\left(Q_{\mathrm{t}}, Q_{\mathrm{t}+\mathrm{m}}\right) / \\
& {\left[\operatorname{variance}\left(Q_{\mathrm{t}}\right) \operatorname{variance}\left(Q_{\mathrm{t}+\mathrm{m}}\right)\right]^{1 / 2} }
\end{aligned}
$$

Meek (2001) presents a semiparametric, iterative method of estimating $\theta$ using SAS macros (SAS Institute, Cary, NC), which was applied to data from the 210-tile, 230-tile, and 330stream sites. Briefly, $\rho(m)$ and $\theta$ were determined on the weekly data, for both $Q$ and $L$, and for regression residuals from fitting of Eq. [1] using ordinary least squares (OLS). Selection of $\theta$ was done considering integration results (Eq. [2]) for these three variates (i.e., $Q, L$, and OLS regression residuals), and at all three sites. A common $\theta$ for the three monitoring stations was selected to suggest a block of time with minimal autocorrelation effects between values, and the weekly data were further averaged across durations of $\theta$ weeks. This time block was selected to be small enough to retain as large a number of points as possible, while large enough to effectively compensate for autocorrelation. Regression analyses were then run on the $\theta$-week averaged data.

To ascribe confidence intervals to regression results, the OLS approach assumes measurement without error for the $X$ variate (in this case $Q$ ). Neglect of this assumption may lead to an attenuated estimate of slope unless the error is considered in the analysis (Kempthorne and Allmaras, 1986). It is not possible to measure hydrologic flows without error. To finalize our estimates of Eq. [1] coefficients for the three monitoring stations, we used two techniques that consider measurement error in the predictor. First, a reduced major axis (RMA) method (Draper, 1991; Mann, 1987) was used, which calculates the geometric mean of the two slopes calculated by OLS regression of $X$ on $Y$ and of $Y$ on $X$. This method does not require knowledge of the measurement error in $X$, but cannot provide confidence intervals for the regression coefficients. The second technique, the method of moments (Fuller, 1987), provides confidence intervals but the measurement error in $X$ must be known or estimated. However, ascribing the measurement error inflates the $r^{2}$ value accordingly.
For this method we estimated a standard error of $5 \%$ for flow measurements (a reliability ratio of 0.95 for untransformed data), based on instrument calibration and rating curve data (unpublished data, 1991-1995).

We considered several additional issues through our analysis. The first was the effect of flooding during 1993. Annual precipitation that year in parts of Iowa (including Walnut Creek) exceeded $1200 \mathrm{~mm}$, which may have been a 1000-yr return event (Pitlick, 1997). In this context, we deemed it appropriate to carry out the analyses with and without the 1993 data. The second issue was the effect of nondetectable concentrations $\left(<1.0 \mathrm{mg} \mathrm{NO}-\mathrm{N} \mathrm{L}^{-1}\right)$. A concentration of $0.5 \mathrm{mg} \mathrm{NO}_{3}-\mathrm{N} \mathrm{L}^{-1}$ was assumed for nondetects (half the detection limit). The effect of this assumption was estimated by also assuming a concentration of zero. This was only necessary for the 330-stream station, as only one sample collected at the tile stations showed a nondetectable concentration.

\section{Denitrification in a Hypothetical Wetland Receiving Tile Drainage}

Given the observed flows and $\mathrm{NO}_{3}-\mathrm{N}$ concentrations, we assessed the potential removal of $\mathrm{NO}_{3}-\mathrm{N}$ from the tile drainage (210- and 230-tile sites) waters through denitrification within constructed wetlands. We used the individual-sample data in this analysis. Tile-drained areas of Iowa are being targeted for installation of constructed wetlands, in part for nutrient removal, using subsidies available under USDA programs (e.g., the Conservation Reserve Enhancement Program, or CREP; see www.fsa.usda.gov/dafp/cepd/crep.htm [verified 2 Dec. 2002]). This was a general assessment, of denitrification alone, based on the following three assumptions.

The first assumption was to size the wetland; a ratio of 0.02 between contributing area and receiving wetland area was assumed, with an average water depth of $0.3 \mathrm{~m}$. Criteria established for Iowa's CREP target this as a maximum area ratio, and limit the extent of water depths greater than $0.9 \mathrm{~m}(\mathrm{~T}$. Isenhart, personal communication, 2001).

The second assumption was to estimate denitrification rate as a function of temperature. We used data reported by Xue et al. (1999), in which constructed-wetland denitrification rates in the Midwest (Illinois) were measured and shown to be consistent with several other studies (e.g., Christensen and Sorensen, 1986; Lindau et al., 1990). An exponential expression was fit between denitrification rate $\left(\mathrm{mg} \mathrm{N} \mathrm{m}^{-2} \mathrm{~h}^{-1}\right)$ and temperature $\left({ }^{\circ} \mathrm{C}\right)$ to the data given in Table 1 of Xue et al. (1999), by analogy estimating denitrification rate as a temperature-governed, first-order process. We omitted two data points reported for dates when nitrate concentrations were nondetectable; nitrate availability rather than temperature could have limited the denitrification rate at these times. Given the small size of the remaining data set $(n=5)$, an iterative procedure was used to obtain the following fitted equation:

$$
D=1.076 \exp (0.097 T)
$$

where $D$ is denitrification rate $\left(\mathrm{mg} \mathrm{N} \mathrm{m}^{-2} \mathrm{~h}^{-1}\right)$ and $T$ is temperature $\left({ }^{\circ} \mathrm{C}\right)$, with $r^{2}=0.91$. The input data spanned a temperature range between 4 and $25^{\circ} \mathrm{C}$, and denitrification rates varied from 2.0 to $11.8 \mathrm{mg} \mathrm{N} \mathrm{m}^{-2} \mathrm{~h}^{-1}$. Implicitly, temperature would affect denitrification rates not only through a direct influence on the metabolism of denitrifying organisms, but also indirectly by stimulating other biological processes (e.g., plant exudation, algal growth, microbial decomposition of organic matter) that in sum consume oxygen and produce available carbon so that denitrification can occur. We note that Xue et al. (1999) provide $\mathrm{K}_{2} \mathrm{SO}_{4}$-extractable carbon data that can also be related to temperature using the same exponential form 
as Eq. [4] with similar statistical precision. Carbon availability could also be affected by the amount of organic sediment, which may take a couple years to develop in a new wetland. The constructed wetlands in the Xue et al. (1999) study were three years old, and the authors assessed their sediments to be "an ideal biochemical environment for denitrifier metabolism." Concentration of $\mathrm{NO}_{3}-\mathrm{N}$ also affects denitrification rates (e.g., Cooper, 1990), but we would not expect a large effect given the range of concentrations that apply here. In the data set used to obtain Eq. [4], concentrations ranged between 4.3 and $10.5 \mathrm{mg} \mathrm{NO}-\mathrm{N} \mathrm{L}^{-1}$. These, along with a $15 \mathrm{mg} \mathrm{NO}_{3}-\mathrm{N} \mathrm{L}^{-1}$ labeled spiking that gave a peak denitrification rate of $9.3 \mathrm{mg} \mathrm{N} \mathrm{m}^{-2} \mathrm{~h}^{-1}$ (Xue et al., 1999), give a range in concentrations similar to those in tile flows of Walnut Creek. Thus we justify applying Eq. [4] to a hypothetical wetland in Walnut Creek because data used to develop this equation came from a constructed wetland with similar climate, surrounding land use, and $\mathrm{NO}_{3}-\mathrm{N}$ concentrations to those found in Walnut Creek, and similar vegetation to what one would expect in a constructed wetland in Walnut Creek.

The third assumption allowed us to estimate the temperature of drainage waters using long-term monthly averages of soil temperature (0.2-m depth), which were obtained from records (1958-1990) at Ames, IA (10 km north of Walnut Creek). An annual cosine function was fit to the data using a procedure described by Meek and Hatfield (1994). The monthly average temperatures were assigned a day-of-year value at the midpoint of each month, so that the fitted expression could be applied to any day of the year (DOY). Results provided the following relation with an $r^{2}$ of 0.99 :

$T=11.45+14.09 \cos [(2 \pi / 365.25)(\mathrm{DOY}-205.9)][5]$

The temperatures obtained using Eq. [5] were between -2.0 and 25.5 for the days of year with recorded flow. We assumed $D=0$ for $T<0$ and $D$ given by Eq. [4] for above-freezing temperatures, that is, between 1.1 and $12.7 \mathrm{mg} \mathrm{N} \mathrm{m}^{-2} \mathrm{~h}^{-1}$.

Given these three assumptions, we examined the effect of detention of drainage waters in this hypothetical wetland employing two alternate scenarios, namely nondetention (outflow $=$ inflow for all flows, and constant storage volume), and indefinite detention (denitrification proceeds at its temperature-regulated potential at all times). Under nondetention, denitrification rates were limited by the supply rate of $\mathrm{NO}_{3}-\mathrm{N}$ in tile waters when the temperature-regulated (loss) rate was estimated to exceed that supply rate. Under the indefinite detention, we assumed that nitrate supply has no influence on denitrification, and simply summed the rates calculated from inferred water temperatures across the entire flow record. These two $\mathrm{NO}_{3}-\mathrm{N}$ detention scenarios provided a range of denitrification estimates under the above-given assumptions of wetland sizing, temperature control of denitrification rates, and ambient temperature domain. Actual detention storage would vary with the design of the wetland and its outflow structure. However, constructed wetlands are typically constrained to a given area, so that storage increases result in greater water depth, which would tend to decrease physical contact of waters with carbon-rich substrates and thereby decrease denitrification. Nevertheless, the two detention scenarios provide reasonable bounds to estimate the potential effect of a constructed wetland on $\mathrm{NO}_{3}-\mathrm{N}$ load, through denitrification.

\section{RESULTS AND DISCUSSION Dates of Record}

Dates with measurable flow that were included in the analysis (Table 1) totaled $2098 \mathrm{~d}$ for the 210-tile site, $2401 \mathrm{~d}$ for the 230 -tile site, and $2299 \mathrm{~d}$ for the 330 -stream site. Differences in record length are mostly explained by early cessation of flow recorded at the 210-tile site in 1993, 1995, and 1999, relative to the 230-tile site. The 1993 flow duration at the 230-tile site may be surprising given the precipitation for that year. However, only $53 \mathrm{~mm}$ of rainfall were recorded in the rain gauge in the 210-tile subbasin after Day 268 that year, and this was received across eight events, the largest being an 11-mm rainfall. Note also that in 1999, stream flow at the 330-stream site ceased before tile flow at the 230tile site ceased. The lower reach of Walnut Creek is within an alluvial valley and is known to lose flow to the surficial aquifer (Burkart et al., 1999). This would explain the earlier cessation of flow at the 330-stream site, given the low flow rates for this period. The 230tile site flows averaged only $0.4 \mathrm{~L} \mathrm{~s}^{-1}$, and never exceeded 1.4 $\mathrm{L} \mathrm{s}^{-1}$ from DOY 273 to 365 in 1999. The data record for all three stations extended through the last day of the year in 1992, 1997, and 1998, when effects

Table 1. Consecutive days of year (DOY) with measurable, ice-free flows as observed in each year from 1992 through 2000 for three monitoring stations (top section). Water flow and $\mathrm{NO}_{3}-\mathrm{N}$ concentration and flux attributes of the data are also summarized (lower section).

\begin{tabular}{|c|c|c|c|}
\hline \multirow[b]{2}{*}{ Year or attribute } & \multicolumn{3}{|c|}{ Monitoring station } \\
\hline & 210-tile site & 230-tile site & 330-stream site \\
\hline 1992, DOY & $210-366$ & $206-366$ & 201-366 \\
\hline 1993, DOY & 68-268 & 64-330 & 64-330 \\
\hline 1994, DOY & 89-344 & 63-344 & 62-337 \\
\hline 1995, DOY & 61-222 & 74-342 & $74-345$ \\
\hline 1996, DOY & 81-355 & 82-349 & $81-352$ \\
\hline 1997, DOY & $55-365$ & $55-365$ & $55-365$ \\
\hline 1998, DOY & $53-365$ & 53-365 & $53-365$ \\
\hline 1999, DOY & 44-258 & 44-365 & 44-273 \\
\hline 2000, DOY & 58-214 & 58-219 & 54-208 \\
\hline Flow duration, d & 2098 & 2401 & 2299 \\
\hline Cumulative flow, $\mathrm{mm}$ & 1559 & 1712 & 1831 \\
\hline Cumulative $\mathrm{NO}_{3}-\mathrm{N}$ flux, $\mathrm{kg} \mathrm{ha}^{-1}$ & 176 & 229 & 168 \\
\hline Mean $\mathrm{NO}_{3}-\mathbf{N}$ (flow-weighted), $\mathrm{mg} \mathrm{L}^{-1}$ & 11.3 & 13.4 & 9.2 \\
\hline Range in $\mathrm{NO}_{3}-\mathrm{N}$ concentration, $\mathbf{m g ~ \mathrm { L } ^ { - 1 }}$ & $<1.0-22.4$ & $3.6-23.5$ & $<1.0-20.9$ \\
\hline Time with $\mathrm{NO}_{3}-\mathrm{N}<10 \mathrm{mg} \mathrm{\textrm {L } ^ { - 1 }}, \%$ & 29 & 19 & 69 \\
\hline Flow with $\mathrm{NO}_{3}-\mathrm{N}<10 \mathrm{mg} \mathrm{L}^{-1}, \%$ & 41 & 26 & 61 \\
\hline Samples/nondetects & $1182 / 1$ & $1454 / 0$ & $2276 / 81$ \\
\hline Catchment area, ha & 493 & 863 & 5134 \\
\hline
\end{tabular}


of freezing conditions on measurement accuracy were not apparent until early January in the following year. The first day of record each year indicates when full thaw was apparent, and omits early and erratic readings during initial snow melt and thaw of stream ice. The first day of record for the 210-tile site in 1994 and 1995 was different from the 230-tile and 330-stream sites, but these discrepancies account for less than $20 \mathrm{~mm}$ of the differences in total water flows from the stations, and less than $2 \mathrm{~kg} \mathrm{ha}^{-1}$ of the cumulative $\mathrm{NO}_{3}-\mathrm{N}$ flux.

The results presented in this paper are from the period of record given in the upper portion of Table 1. Because of this, and because of a minimal reliance on estimation techniques for periods of missing record, and use of $0.5 \mathrm{~h}$ flow data to calculate sample-interval loads, annual loads given here are slightly different than those reported elsewhere (e.g., Jaynes et al., 1999), where the flow record consists of longer-period averages, and a somewhat greater portion of the record is derived from estimated values. We consider these differences an acceptable consequence of using techniques appropriate to the task at hand.

Results under the three stated objectives are discussed separately in the following three sections.

\section{Data Summary (Objective 1)}

Cumulative flows of water and $\mathrm{NO}_{3}-\mathrm{N}$, expressed on an area-weighted basis, showed variations between the stations (Table 1). The tile outlets generally had lesser water flow, but greater nitrate concentrations relative to the 330-stream site, and this led to larger estimates of $\mathrm{NO}_{3}-\mathrm{N}$ loads for the 210- and 230-tile sites (Table 1). Nitrate $\mathrm{N}$ concentrations at the tile sites were predominantly greater than the $10 \mathrm{mg} \mathrm{L}^{-1}$ drinking-water standard, when expressed on either a time-weighted or a flow-weighted basis, but only about one-third of the flows from the watershed outlet (330-stream site) exceeded this standard (Table 1). Year-to-year differences in precipitation, flows, and concentration data were important features of the data (Fig. 2). In fact, differences in cumulative flows between stations are largely due to differences that occurred during the 1993 flood year. The largest flows in 1993 overwhelmed the subsurface drainage systems; some flood waters bypassed the tile outlets, but then were measured at the 330-stream site. The 1993 floods also had the apparent effect of flushing stored soil $\mathrm{N}$ from the catchment, as evidenced by smaller $\mathrm{NO}_{3}-\mathrm{N}$ concentrations in 1993 and 1994.

Precipitation measurements showed good consistency between the subbasins, although the 210-tile subbasin had somewhat less rainfall recorded than the other stations in 1993 and 1995 (Fig. 2A). The data record includes years of flood $(1993,1998)$, significant drought (2000), and near-average (1994-1997, 1999) conditions (Fig. 2A,B). Flow-weighted $\mathrm{NO}_{3}-\mathrm{N}$ concentrations were greater than $10 \mathrm{mg} \mathrm{L}^{-1}$ at all three stations in five of the nine years. Across the record, the 230-tile site had the largest flow-weighted $\mathrm{NO}_{3}-\mathrm{N}$ concentrations, compared with the other two stations, in every year except 2000 (Fig. 2C), and the largest $\mathrm{NO}_{3}-\mathrm{N}$ loads in every
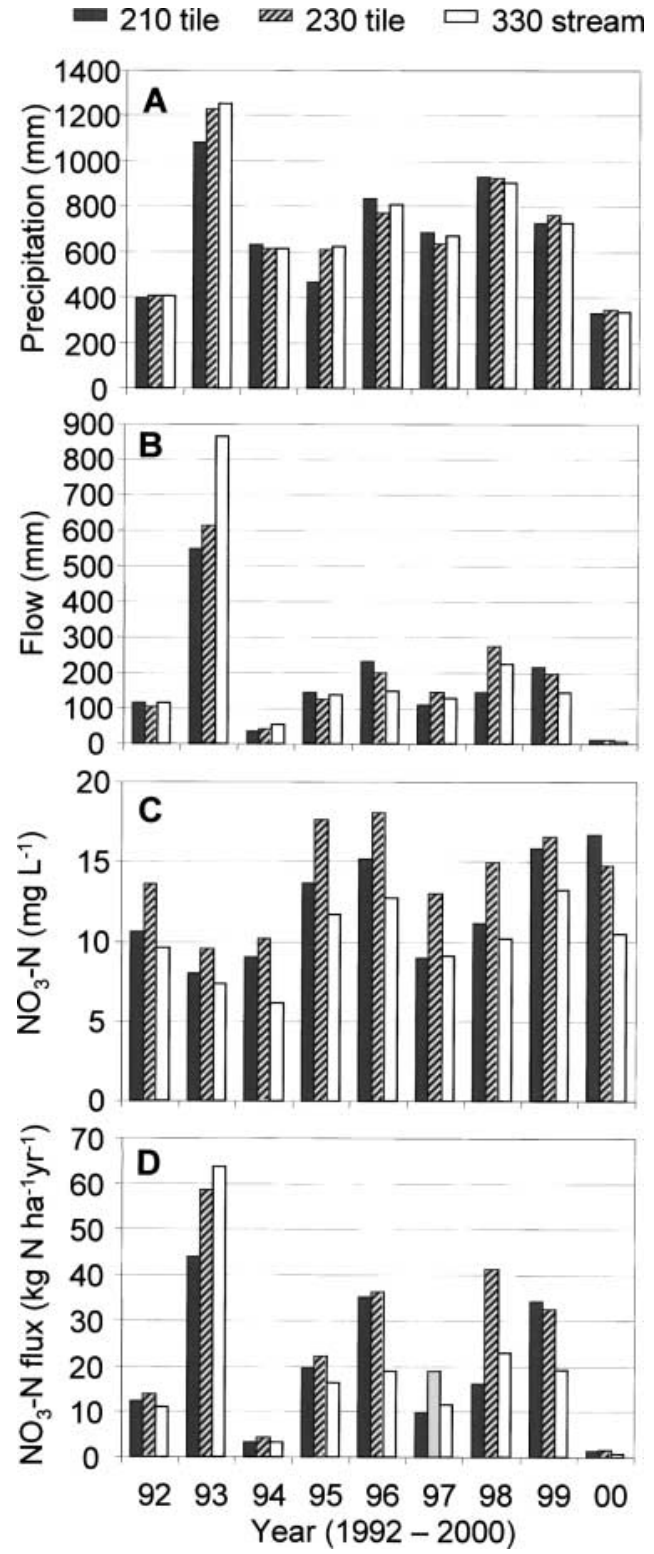

Fig. 2. Annual summaries of $(A)$ precipitation, $(B)$ streamflow, $(C)$ flow-weighted $\mathrm{NO}_{3}-\mathrm{N}$ concentration, and $(D) \mathrm{NO}_{3}-\mathrm{N}$ flux for the three monitoring stations. Summaries are cumulative across dates given in Table 1, except precipitation, which is totaled for the entire year from 1993 through 2000. In particular, note that the record in 1992 begins after the 201st day.

year except 1993 and 1999. Several factors could contribute to larger $\mathrm{NO}_{3}-\mathrm{N}$ concentrations in the 230-tile site than the 210-tile site. These include differences in fertility management, soil mineralization, and/or in the structure of the drainage networks in the two subbasins (e.g., more surface water inlets in the 210-tile subbasin would presumably result in smaller $\mathrm{NO}_{3}-\mathrm{N}$ concentrations). Also, nearly $94 \%$ of the 230 -tile subbasin is row cropped, as compared with $88 \%$ of the 210 -tile subbasin (unpublished data, 1991-1997). Smaller mean concentrations at the outlet than the tile sites were caused by several factors discussed below under Objective 2.

Stream-flow export of $\mathrm{NO}_{3}-\mathrm{N}$ changed according to differences in flow across the years, with small loads in 

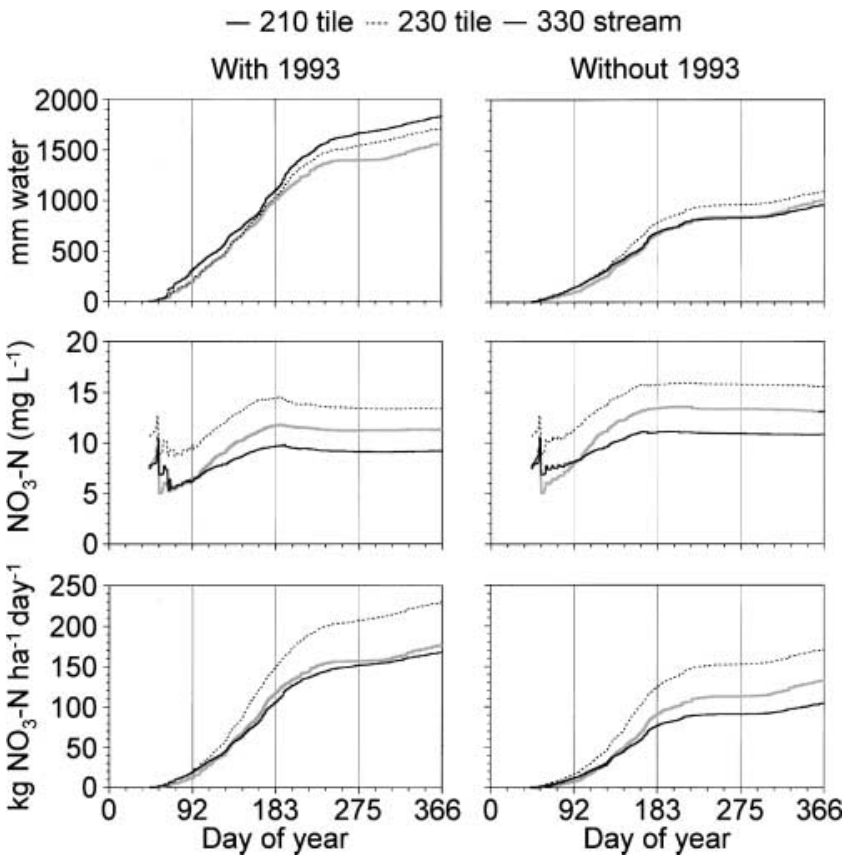

Fig. 3. Distribution of cumulative water flows (top), flow-weighted $\mathrm{NO}_{3}-\mathrm{N}$ concentrations (center), and cumulative mass export of nitrate $\mathbf{N}$ (bottom), according to date, given the period of record described in Table 1. The plots in the right column are the same but omit the 1993 flood year.

the low-flow years of 1994 and 2000 (Fig. 2D). Loads exceeded $20 \mathrm{~kg} \mathrm{ha}^{-1} \mathrm{yr}^{-1}$ at both tile outlets in four of the nine years $(1993,1995,1996,1999)$, but only two of the nine years at the 330-stream site $(1993,1998)$, coinciding with the years of flooding. The 1993 floods had a large influence on the cumulative data (Fig. 2), accounting for about $19 \%$ of the precipitation received during the period of record, but about $35 \%$ of the water flows and $25 \%$ of the $\mathrm{N}$ loads for the tile sites (210- and 230 -tile sites), and about $47 \%$ of the water flows and $35 \%$ of the $\mathrm{N}$ loads at the watershed outlet (330stream site).

Most flows of water and $\mathrm{NO}_{3}-\mathrm{N}$ during the year occurred during the second quarter (i.e., DOY 92-183; see Fig. 3). Row crops in Iowa are planted usually beginning after DOY 120; therefore, the crop is either not present or not fully established during most of this period. Flows decreased after the second quarter because evapotranspiration increases as the crops become fully established, and because late summer and early autumn tends to be dry. Nitrate $\mathrm{N}$ concentrations also decreased, generally, after the second quarter (Fig. 4), which is attributed to leaching and crop uptake of available $\mathrm{N}$ as the growing season progresses. After removing the 1993 data, flowweighted $\mathrm{NO}_{3}-\mathrm{N}$ concentrations increased at all three stations given the remaining record, from 11.3 to $13.1 \mathrm{mg}$ $\mathrm{L}^{-1}$ at the 210 -tile site, from 13.4 to $15.5 \mathrm{mg} \mathrm{L}^{-1}$ at the 230-tile site, and from 9.2 to $10.8 \mathrm{mg} \mathrm{L}^{-1}$ at the watershed outlet (330-stream site). This occurred because many of the large flows with small $\mathrm{NO}_{3}-\mathrm{N}$ concentrations were recorded in 1993 (Fig. 4).

Duration curves for water flows $\left(\mathrm{mm} \mathrm{h}^{-1}\right), \mathrm{NO}_{3}-\mathrm{N}$ concentrations $\left(\mathrm{mg} \mathrm{L}^{-1}\right)$, and $\mathrm{NO}_{3}-\mathrm{N}$ flux $\left(\mathrm{kg} \mathrm{N} \mathrm{ha}^{-1}\right.$
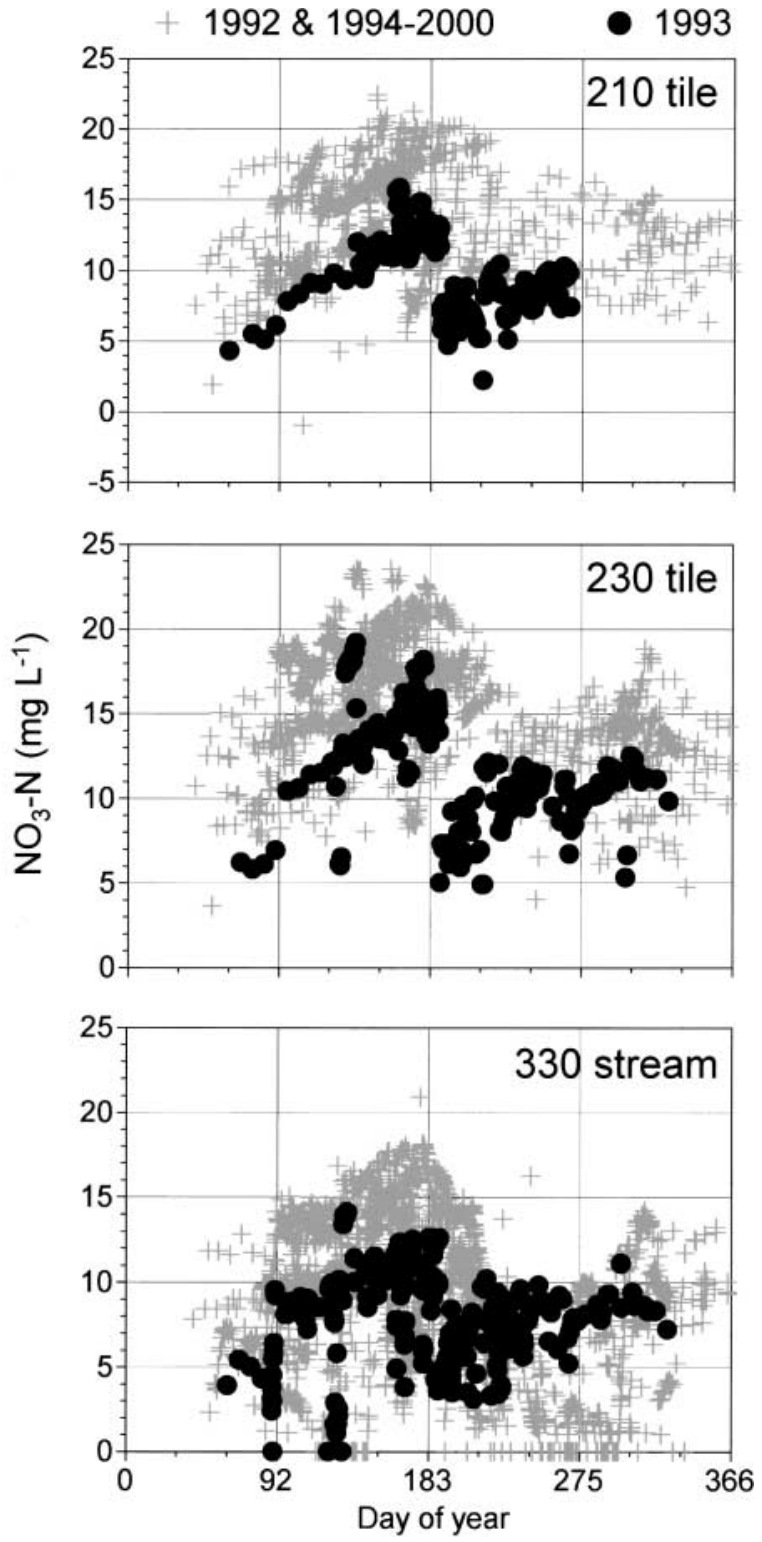

Fig. 4. Distribution of $\mathrm{NO}_{3}-\mathrm{N}$ concentrations by day of year for each of the monitoring stations, with data from the 1993 flood year distinguished. Nondetects $\left(<\mathbf{~ m g ~} \mathrm{NO}_{3}-\mathrm{N} \mathrm{L}^{-1}\right)$ are plotted at $0 \mathrm{mg} \mathrm{L}^{-1}$.

$\mathrm{d}^{-1}$ ) are shown in Fig. 5. Large flows, while not frequent, delivered a large fraction of the discharge. Specifically, flows exceeding $0.1 \mathrm{~mm} \mathrm{~h}^{-1}$ occupy 6 to $10 \%$ of the record, but delivered 37 to $51 \%$ of the cumulative flow volume, depending on the station. If 1993 data are omitted, then these large flows occupied between 2 and $5 \%$ of the record, but delivered 22 to $37 \%$ of the total flow volume. Nitrate $\mathrm{N}$ concentrations exceeded the $10 \mathrm{mg}$ $\mathrm{L}^{-1}$ drinking water standard $71 \%$ of the time $(1449 \mathrm{~d})$ at the 210 -tile site, $81 \%$ of the time (1946 d) at the 230 tile site, but only $31 \%$ of the time (718 d) at the 330 stream site (see Table 1). Much of the $\mathrm{NO}_{3}-\mathrm{N}$ load occurred during larger flow events. Flux rates exceeding $0.1 \mathrm{~kg} \mathrm{ha}^{-1} \mathrm{~d}^{-1}$ occurred $25 \%$ of the time at the 210 tile site, $31 \%$ of the time at the 230 -tile site, and $23 \%$ of the time at the watershed outlet (Fig. 5). However, 

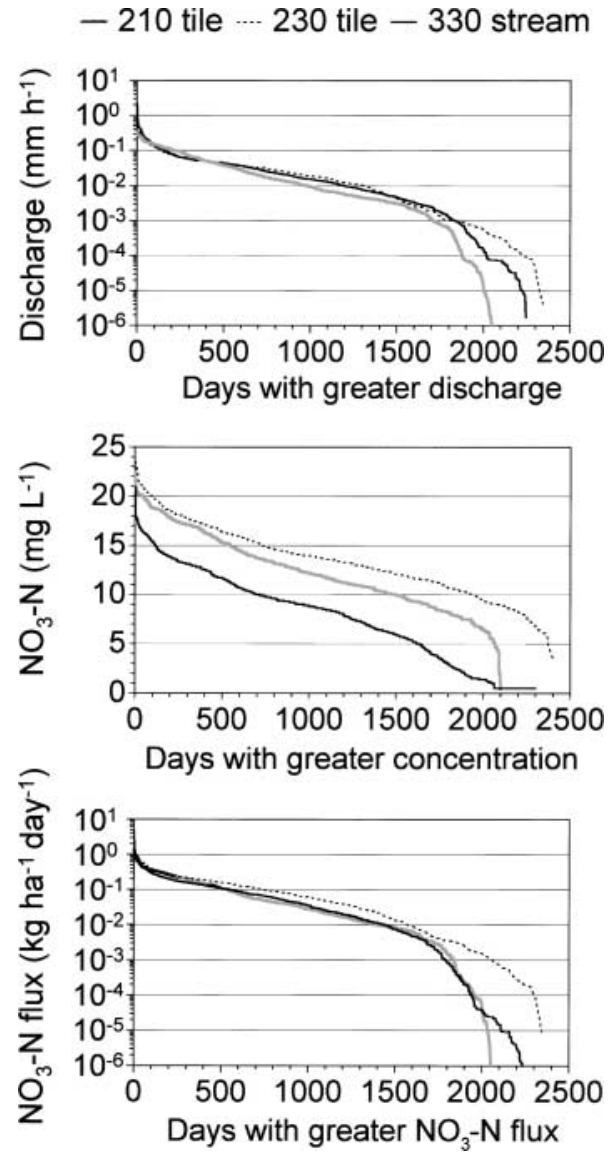

Fig. 5. Frequency-duration plots for water flows, $\mathrm{NO}_{3}-\mathrm{N}$ concentrations, and $\mathrm{NO}_{3}-\mathrm{N}$ fluxes for the three monitoring stations.

these fluxes account for $79 \%$ of the $\mathrm{NO}_{3}-\mathrm{N}$ loads at the two tile main sites, and $74 \%$ of the total load at the outlet. This result has implications for the design of headwater stream modifications, such as constructed wetlands, which may be installed for water quality benefits in artificially drained agricultural watersheds, as discussed under Objective 3 results.

Univariate statistics for weekly flows and $\mathrm{NO}_{3}-\mathrm{N}$ fluxes (Table 2) also illustrate the variability of the data. Particularly, note that standard deviations exceed means (coefficients of variation exceed 100\%). The weekly data fail a range of normality tests, even when logtransformed, and fits to alternative, skewed distributions are not readily discerned from one another.

\section{Flow-Nitrate Nitrogen Flux Relationships (Objective 2)}

Autocorrelograms of water and nitrate flux revealed that most autocorrelation in the data sets could be removed by aggregating the data across seven-week periods. These aggregate data, along with the original sample data, are plotted in Fig. 6 for the three monitoring stations. The plots allow visual comparison of the individual-sample and aggregate data sets, and illustrate the relative range and scatter in the data sacrificed to minimize autocorrelation. Examining the individualsample data (gray crosses) in Fig. 6, it is apparent that
Table 2. Product-moment univariate statistics for water flow rates and $\mathrm{NO}_{3}-\mathrm{N}$ flux rates calculated from one-week aggregate data.

\begin{tabular}{|c|c|c|c|c|}
\hline Variable & Statistic & $\begin{array}{c}\text { 210-tile } \\
\text { site } \\
(n=292)\end{array}$ & $\begin{array}{c}\text { 230-tile } \\
\text { site } \\
(n=335)\end{array}$ & $\begin{array}{c}\text { 330-stream } \\
\text { site } \\
(n=318)\end{array}$ \\
\hline \multirow[t]{4}{*}{ Water flow, $\mathbf{m m ~ \mathbf { h } ^ { - 1 }}$} & mean & 0.03 & 0.03 & 0.04 \\
\hline & SD & 0.05 & 0.05 & 0.09 \\
\hline & skewness & 1.97 & 3.87 & 4.72 \\
\hline & kurtosis & 3.55 & 22.70 & 26.82 \\
\hline \multirow[t]{4}{*}{$\mathrm{NO}_{3}-\mathrm{N}$ flux, $\mathrm{kg} \mathrm{ha}^{-1} \mathrm{~d}^{-1}$} & mean & 0.09 & 0.10 & 0.09 \\
\hline & SD & 0.14 & 0.15 & 0.15 \\
\hline & skewness & 2.39 & 2.83 & 3.75 \\
\hline & kurtosis & 6.55 & 11.25 & 20.93 \\
\hline
\end{tabular}

low flows were sampled more frequently at the 330stream site than at the two drain sites, perhaps because stable, but significant, tile flows partly infiltrated the streambed and became measured as small flows at the outlet. Considering this difference, though, the low flows at the stream site had smaller $\mathrm{NO}_{3}-\mathrm{N}$ concentrations than those at the tile drains (Fig. 6). Three general processes are plausible contributors to this, all of which may have operated to some degree. The first is the greater contact between the water and streambed materials at low flows (Alexander et al., 2000), which enhances the opportunity for $\mathrm{NO}_{3}-\mathrm{N}$ losses via denitrification, and via uptake by aquatic and riparian plants. Second, ground water baseflow contributions, consisting of streambank return flows and/or longer-term resident ground waters originating along upper and middle reaches of the stream network, may be dominant during low flows. Both sources of baseflow could be subject to denitrification in the saturated zone over time periods sufficient to diminish nitrate concentrations. Third, lands adjacent to the lower reach of Walnut Creek are dominantly woodland and pasture, and drainage from these areas (along artificial or natural pathways) could dilute drainage contributed from cropped lands.

Several studies have shown increases in nitrate concentration in downstream reaches relative to upstream reaches, but this is related to land use, as urbanization or agricultural land uses are intensified in the lower parts of many watersheds (e.g., Castillo et al., 2000). In Walnut Creek watershed, however, the only forested area is in the naturally developed riparian valley along the lower third of the stream network.

The highest flows at the 330-stream site frequently had relatively small $\left(<10 \mathrm{mg} \mathrm{L}^{-1}\right)$ concentrations (Fig. 6). However, most of the data points with high flow and low concentration at this site were recorded in the flood year of 1993. A similar pattern might be anticipated for high flows from the tile drains, because these large flows included those surface runoff waters entering into tile inlets. However, no dilution of large flows is evident for the two tile mains.

Results of regression analyses (Table 3 ) indicate similarity in the relationships between water flow and $\mathrm{NO}_{3}-\mathrm{N}$ flux for the two tile outlet sites (210- and 230-tile sites). The slopes $(b)$ of these relationships are not greatly different than 1 , indicating that a $1 \%$ change in flow, on average, was consistent with about a $1 \%$ change in $\mathrm{NO}_{3}-\mathrm{N}$ flux. This results from concentration being essentially independent of flow, and indeed, regression 
+ sample data

- seven-week aggregate data
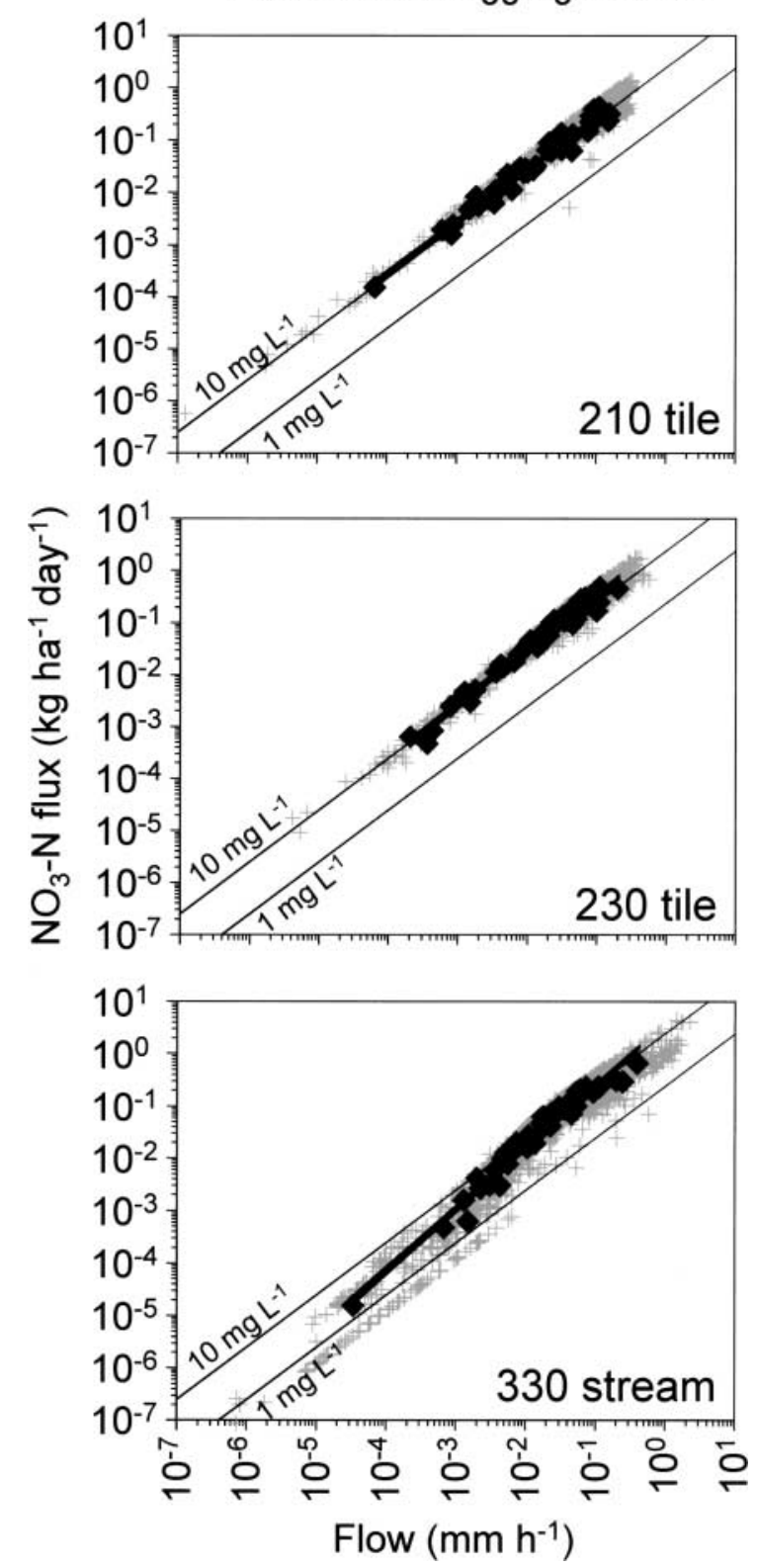

Fig. 6. Relationships between water flows and $\mathrm{NO}_{3}-\mathrm{N}$ fluxes for the 210- and 230-tile drains, and the 330-stream site. Iso-lines (10 and $1.0 \mathrm{mg} \mathrm{L}^{-1}$ ) provide orientation to interpret $\mathrm{NO}_{3}-\mathrm{N}$ concentrations. Individual samples with $\mathrm{NO}_{3}-\mathrm{N}$ concentrations less than $1.0 \mathrm{mg}$ $\mathbf{L}^{-1}$ (the detection limit) are plotted at $0.5 \mathrm{mg} \mathrm{L}^{-1}$. Best-fit lines shown are those determined using the reduced major axis method (coefficients given in Table 3).

of flow versus concentration (individual sample data) shows that less than $5 \%$ of the variation in concentrations is explained by flow at the two tile mains, either by linear or log-linear expression. However, the stream outlet (330-stream site) shows a slope greater than one, resulting from smaller concentrations at low flows. At this site concentration is related to $\ln (Q)$ for the individual sample data with an $r^{2}$ of 0.16 . This apparently contrasts results given by Jaynes et al. (1999) that, based on the 1992-1995 record at the 330-stream site, $\mathrm{NO}_{3}-\mathrm{N}$ concentrations were more likely to increase when flow decreased and more likely to decrease when flow increased. However, across this longer record any such trend was weak. Across all individual sample intervals, concentrations increased in $54 \%$ of the intervals when flow decreased, and decreased in $48 \%$ of the intervals when flow increased. A zero change in concentration was measured in $13 \%$ of the intervals, whether flow increased or decreased.

These comparative plots (Fig. 6) highlight the change that can occur in flow-nutrient flux relationships at different points within a small (second-order) agricultural watershed. Similar plots could be used to compare different locations or perhaps paired watershed studies. Paired watershed assessments have often focused on assessing event-response relationships, under different land management practices. But analysis of flownutrient flux relationships considers the full range of event and baseflows, and may be a useful alternative for analysis in a number of studies considering patterns of water quality within watersheds.

Regression results were applied to the data with nondetectable concentrations $\left(<1.0 \mathrm{mg} \mathrm{L}^{-1}\right)$ assigned a value of $0.5 \mathrm{mg} \mathrm{L}^{-1}$. This applied to 81 of the samples from the 330 -stream site (3.6\% frequency), but only one of the tile-site samples. Nondetects tended to occur during low-flow conditions. Therefore, decreasing these assigned concentrations to zero resulted in a slight increase in the slope of the regression lines, from about 1.2 to about 1.27. Confidence intervals for $b$ (Table 3 ) shifted to similarly larger values.

These regressions were also run without data from the 1993 flood year to assess the influence of that year's data on the results. Because 1993 data were dominantly large flows with small concentrations, their exclusion resulted in greater slopes and intercepts being calculated for Eq. [1] parameters, though these greater values were within confidence intervals established using all the data (Table 3). Regardless of inclusion or exclusion of the 1993 data, the slopes of the tile drain sites were close to 1.0 , whereas the 330 -stream site had a slope greater than 1.0.

\section{Treatability of Nitrate Nitrogen Fluxes Using Constructed Wetlands (Objective 3)}

Two scenarios were used to estimate possible denitrification of tile $\mathrm{NO}_{3}-\mathrm{N}$ fluxes in a hypothetical constructed wetland. Under the scenario of indefinite detention of nitrate within a wetland, potential denitrification rates were calculated using Eq. [4] and [5], and summed for the entire flow record. Given these assumptions, wetland denitrification could have removed $34 \%(59 \mathrm{~kg})$ of the cumulative $\mathrm{NO}_{3}-\mathrm{N}$ flux from the 210-tile site, and $28 \%(65 \mathrm{~kg})$ of the cumulative flux from the 230-tile site during the period of monitoring. The difference in mass occurs because of the difference in length of the flow record.

Under the other scenario of no detention storage of nitrate in the wetland, denitrification was not permitted to exceed the inflow rate of nitrate. Given this scenario, denitrification could have removed $21 \%(36 \mathrm{~kg})$ of the 
Table 3. Regression coefficients relating water flow and $\mathrm{NO}_{3}-\mathrm{N}$ flux for the 210-tile, 230-tile, and 330-stream sites by Eq. [1], as calculated using seven-week aggregate data. Reduced major axis (RMA) and method-of-moments results are given, with confidence intervals for the method of moments. The $r^{2}$ values for the method of moments are inflated by including the estimated measurement error of $5 \%$ (see text). Data are plotted in Fig. 5, and the coefficients $a$ and $b$ are defined by Eq. [1].

\begin{tabular}{|c|c|c|c|c|c|}
\hline \multirow[b]{2}{*}{ Station } & \multicolumn{2}{|c|}{ RMA method } & \multicolumn{3}{|c|}{ Method of moments } \\
\hline & Intercept (a) & Slope $(b)$ & Intercept (a) $(95 \%$ CI) & Slope $(b)(95 \%$ CI $)$ & $r^{2}$ \\
\hline \multicolumn{6}{|c|}{1993 included } \\
\hline 210 tile & 2.91 & 1.01 & $3.02(2.03,4.49)$ & $1.02(0.95,1.10)$ & 0.995 \\
\hline 230 tile & 4.05 & 1.06 & $4.25(3.15,5.73)$ & $1.07(1.01,1.14)$ & 0.999 \\
\hline 330 stream & 4.12 & 1.19 & $3.95(2.64,5.92)$ & $1.18(1.09,1.28)$ & 0.973 \\
\hline \multicolumn{6}{|c|}{1993 excluded } \\
\hline 210 tile & 3.49 & 1.05 & $3.66(2.59,5.17)$ & $1.06(0.99,1.12)$ & 0.997 \\
\hline 230 tile & 5.13 & 1.10 & $5.22(3.59,7.61)$ & $1.10(1.02,1.19)$ & 0.996 \\
\hline 330 stream & 6.38 & 1.27 & $6.60(4.45,9.78)$ & $1.28(1.19,1.37)$ & 0.992 \\
\hline
\end{tabular}

cumulative $\mathrm{NO}_{3}-\mathrm{N}$ flux at the 210-tile site and $18 \%(41$ $\mathrm{kg}$ ) of the cumulative flux at the 230-tile site. If the 1993 flows are neglected, denitrification in a constructed wetland could have removed between 22 and $40 \%$ (29 to $53 \mathrm{~kg}$ ) of the $\mathrm{NO}_{3}-\mathrm{N}$ flux from the 210 -tile site, and between 19 and $33 \%$ (33 to $57 \mathrm{~kg}$ ) of the $\mathrm{NO}_{3}-\mathrm{N}$ flux at the 230-tile site, depending on which detention scenario is used. We view the zero-detention estimates as being realistic, with the indefinite detention scenario providing estimates that are optimistic, but perhaps feasible. But we have ignored the fact that water depth increases under high flows, and this can limit availability of carbon that is needed for denitrification. The estimates are for denitrification only, and neglect other wetland sinks such as seepage and assimilation. However, nitrogen assimilated by wetland plants could be released (become a source of $\mathrm{N}$ in the long term) unless the biomass is harvested. Also, seepage losses would vary considerably depending on the hydrogeologic setting. Xue et al. (1999) suggested that seepage was an important loss pathway in their study wetlands, but subsurface hydraulic conditions were not measured. Significant seepage losses through the clay till sediments dominant in the upland drainage ditches of Walnut Creek watershed would not be anticipated; very slow permeability is the reason these areas have been artificially drained. Regionally, however, some tile outlets discharge to channels underlain by alluvial sediments that could allow significant surficial-aquifer recharge.

Most of the estimated reductions in $\mathrm{NO}_{3}-\mathrm{N}$ loads would occur during periods of low flow, given the scenario of zero detention (Fig. 7). At the 210-tile site, only about $7 \mathrm{~kg} \mathrm{ha}^{-1}$ of the total estimated denitrification of $36 \mathrm{~kg} \mathrm{ha}^{-1}$ would have occurred when flows exceeded $0.1 \mathrm{~mm} \mathrm{~h}^{-1}$. These large flows, however, contained $52 \%$ of the water and $48 \%$ of the $\mathrm{NO}_{3}-\mathrm{N}$ that flowed past this site. Half of the denitrification would have occurred during low flows (less than about $0.026 \mathrm{~mm} \mathrm{~h}^{-1}$ ), when only $14 \%$ of the total water flow and $15 \%$ of the $\mathrm{NO}_{3}-\mathrm{N}$ load was delivered. If 1993 data are omitted, then $10 \%$ of the $30 \mathrm{~kg} \mathrm{ha}^{-1}$ of denitrification would have occurred when flow rates exceeded $0.1 \mathrm{~mm} \mathrm{~h}^{-1}$, with these flows carrying $37 \%$ of the water discharge and $39 \%$ of the $\mathrm{NO}_{3}-\mathrm{N}$ load.

Similar estimates were generated for the 230-tile site, considering the longer flow duration and greater mean $\mathrm{NO}_{3}-\mathrm{N}$ concentrations at this site (Table 2). Only about 6 out of $41 \mathrm{~kg} \mathrm{ha}^{-1}$ of total denitrification would have occurred when flows exceeded $0.1 \mathrm{~mm} \mathrm{~h}^{-1}$, with these flows carrying $37 \%$ of the water and $33 \%$ of the $\mathrm{NO}_{3}-\mathrm{N}$ load. Half the total denitrification would have occurred when flows were less than about $0.033 \mathrm{~mm} \mathrm{~h}^{-1}$, with these flows carrying about $20 \%$ of the water and $\mathrm{NO}_{3}-\mathrm{N}$ load. If 1993 data are neglected, then only $6 \%$ of the $33 \mathrm{~kg} \mathrm{~N} \mathrm{ha}{ }^{-1}$ of denitrification would have occurred when flow rates exceeded $0.1 \mathrm{~mm} \mathrm{~h}^{-1}$, with these large flows carrying about $24 \%$ of the water and $\mathrm{NO}_{3}-\mathrm{N}$ loads. Half the loss would have occurred at flow rates less than $0.026 \mathrm{~mm} \mathrm{~h}^{-1}$, when again about $20 \%$ of the cumulative flows of water and $\mathrm{NO}_{3}-\mathrm{N}$ passed the 230-tile site. We reemphasize here that these estimated denitrification rates are for each hectare of cropland, if the wetland area installed was $2 \%$ of the cropland area. Denitrification totals should, therefore, be multiplied by 50 to obtain estimates per hectare of wetland. Constructed wetlands, we estimate, would decrease flow-weighted nitrate concentrations by between 2.4 and $3 \mathrm{mg} \mathrm{L}^{-1}$, under the zero-detention assumption.

\section{SUMMARY AND CONCLUSIONS}

Long-term records from small tile-drained watersheds in the U.S. Midwest are rare. This data set provided a basis to evaluate water discharge and nutrient

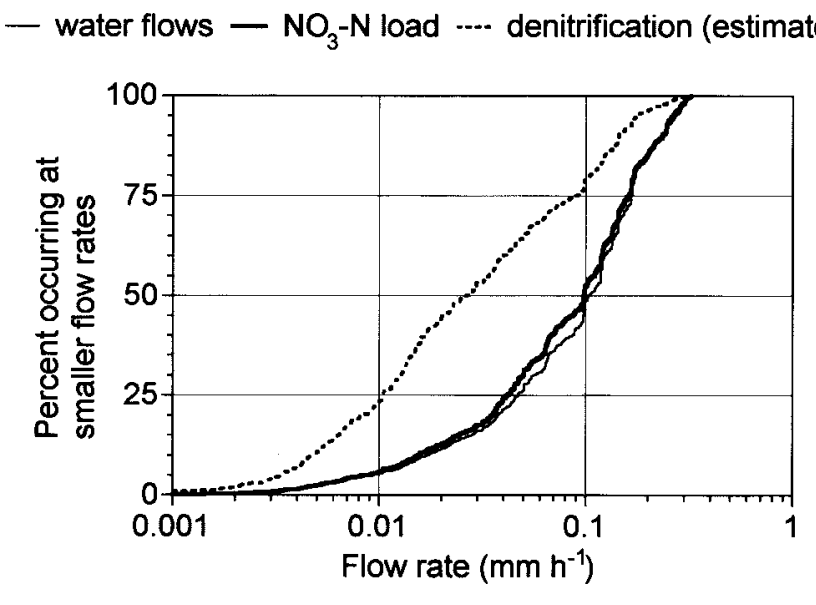

Fig. 7. Cumulative frequencies of water flows, $\mathrm{NO}_{3}-\mathrm{N}$ fluxes, and estimated denitrification in a hypothetical wetland at the 210-tile site, sorted according to water flow rate. Denitrification estimates are based on a scenario of zero detention for the wetland, under which temperature and $\mathrm{NO}_{3}-\mathrm{N}$ supply rate could limit denitrification. 
fluxes from a second-order watershed and two of its tiledrained subbasins, under agricultural land use typical of the region. Export of $\mathrm{NO}_{3}-\mathrm{N}$ from the catchment was $168 \mathrm{~kg} \mathrm{ha}^{-1}$ during the period of record, while export from the tile-drained subbasins was 176 and $229 \mathrm{~kg} \mathrm{ha}^{-1}$. The greater export occurred from the larger subbasin, which had a larger flow-weighted nitrate concentration (13.4 vs. $11.3 \mathrm{mg} \mathrm{L}^{-1}$ ) and larger flow volume (1712 vs. $1559 \mathrm{~mm}$ ) than the smaller subbasin. The watershed outlet flow volume was $1831 \mathrm{~mm}$, which had a flowweighted mean $\mathrm{NO}_{3}-\mathrm{N}$ concentration of $9.2 \mathrm{mg} \mathrm{L}{ }^{-1}$. Concentrations of nitrate commonly exceeded the drinking water standard of $10 \mathrm{mg} \mathrm{L}^{-1}$, but the frequency of exceedance was diminished from the tile-drained basins (approximately $70-80 \%$ of the time) to the watershed outlet (approximately $30 \%$ of the time).

Across the record, large flows with small $\mathrm{NO}_{3}-\mathrm{N}$ concentrations were predominantly from measurements made during the flood year of 1993. Flows occurring during the second quarter of the year, before full establishment of the crop, carried most of the $\mathrm{NO}_{3}-\mathrm{N}$ load. Flux rates exceeding $0.1 \mathrm{~kg} \mathrm{ha}^{-1} \mathrm{~d}^{-1}$ occurred 23 to $31 \%$ of the time, but these flows account for 74 to $79 \%$ of the $\mathrm{NO}_{3}-\mathrm{N}$ loads at the three sites. Similarly, large water flows $\left(>0.1 \mathrm{~mm} \mathrm{~h}^{-1}\right)$ occurred 6 to $10 \%$ of the time, but accounted for 37 to $51 \%$ of the cumulative flow volume.

At the outlet, small flows tended to have smaller $\mathrm{NO}_{3}-\mathrm{N}$ concentrations, but no such trend was clear for either subbasin. We established a log-linear relationship between flow and $\mathrm{NO}_{3}-\mathrm{N}$ flux for each of the three stations. For the subbasins, this relationship had a slope, or "elasticity" coefficient, of about 1.0, whereas the outlet had a coefficient of about 1.2. We employed specific methods to account for autocorrelation and measurement error in the analysis that allowed us to calculate confidence intervals for coefficients defining the flowflux relationship. This approach should be generally useful in comparing water quality records between watersheds or between locations within a watershed, provided a sufficient record is available. Flow-flux relationships can change within a small, second-order drainage basin, with a downstream increase in the elasticity coefficient demonstrated in the case of this watershed dominated by tile drainage. Results show that nitrate concentrations were not typically diluted by large flows, with the 1993 floods being the major exception.

We also estimated how effective constructed wetlands might be in denitrifying $\mathrm{NO}_{3}-\mathrm{N}$ fluxes from the tiledrained subbasins. Depending on detention of nitrate in the wetland, and the subbasin flows input to this hypothetical wetland, denitrification could remove 18 to $34 \%$ of the $\mathrm{NO}_{3}-\mathrm{N}$ fluxes, assuming the wetland meets criteria for USDA support (i.e., $0.3 \mathrm{~m}$ deep and 0.02 ha in area per hectare of contributing cropland). Because $\mathrm{NO}_{3}-\mathrm{N}$ concentrations are not diluted by large flows, much of the $\mathrm{NO}_{3}-\mathrm{N}$ load is delivered with large flows. Constructed wetlands cannot effectively denitrify $\mathrm{NO}_{3}-\mathrm{N}$ delivered with large flows, and thus may not achieve water quality goals with out additional measures. Therefore, practices to optimize nitrogen management within fields should also be encouraged. In particular, spring applications of $\mathrm{N}$ to target crop requirements, rather than large, agronomically conservative applications in autumn, should be beneficial. Research conducted on this topic within Walnut Creek will be reported in a future paper that is under preparation.

\section{ACKNOWLEDGMENTS}

This long-term effort required a significant effort by a large number of individuals, and this is much appreciated. Kevin Cole, Bob Jaquis, Donna Schmitz, Karen Keck, Jeff Nichols, Williams Tharrington, Tim Hart, Scott Farris, and Wolf Oesterreich are among those who provided support to field activities and data management efforts. Thanks also to Wolf Oesterreich for producing Figure 1. The NSTL Analytical Laboratory provided consistent and high-quality data on $\mathrm{NO}_{3}-\mathrm{N}$ concentrations in water samples. This effort was supervised by Amy Morrow, with staff including Diane Farris, Tim Watts, David DenHaan, Brenda Schwartz, and John Kennedy.

\section{REFERENCES}

Alexander, R.B., P.S. Murdoch, and R.A. Smith. 1996. Streamflowinduced variations in nitrate flux in tributaries to the Atlantic coastal zone. Biogeochemistry 33:149-177.

Alexander, R.B., R.A. Smith, and G.E. Schwarz. 2000. Effect of stream channel size on the delivery of nitrogen to the Gulf of Mexico. Nature (London) 403:758-761.

Bjorneberg, D.L., D.L. Karlen, R.S. Kanwar, and C.A. Cambardella. 1998. Alternative $\mathrm{N}$ fertilizer management strategies effects on subsurface drain effluent and $\mathrm{N}$ uptake. Appl. Eng. Agric. 14:469473.

Bolton, E.F., J.W. Aylesworth, and F.R. Hore. 1970. Nutrient losses through tile drains under three cropping systems and two fertility levels on a Brookston clay. Can. J. Soil Sci. 50:275-279.

Burkart, M.R., and D.E. James. 1999. Agricultural-nitrogen contributions to hypoxia in the Gulf of Mexico. J. Environ. Qual. 28:850-859.

Burkart, M.R., W.W. Simpkins, P.J. Squillace, and M. Helmke. 1999. Tributary stream infiltration as a source of herbicides in an alluvial aquifer. J. Environ. Qual. 28:69-74.

Castillo, M.M., J.D. Allan, and S. Brunzell. 2000. Nutrient concentrations and discharges in a Midwestern agricultural catchment. J. Environ. Qual. 29:1142-1151.

Christensen, P.B., and J. Sorensen. 1986. Temporal variation of denitrification activity in a plant-covered, littoral sediment from Lake Hampen, Denmark. Appl. Environ. Microbiol. 51:1174-1179.

Cooper, A.B. 1990. Nitrate depletion in the riparian zone and stream channel of a small headwater catchment. Hydrobiologia 202:13-26.

Cressie, N.A.C. 1993. Statistics for spatial data. John Wiley \& Sons, New York.

Draper, N. 1991. Straight line regression when both variables are subject to error. p. 1-18 In G.H. Milliken and J.R. Schwenke (ed.) Proc. 1991 KSU Conf. Appl. Stat. Agric., Kansas State Univ., Manhattan, KS. 28-30 Apr. 1991. Kansas State Univ., Manhattan, KS.

David, M.B., and L.E. Gentry. 2000. Anthropogenic inputs of nitrogen and phosphorus and riverine export for Illinois, USA. J. Environ. Qual. 29:494-508.

Dinnes, D.L., D.L. Karlen, D.B. Jaynes, T.C. Kaspar, J.L. Hatfield, T.S. Colvin, and C.A. Cambardella. 2002. Nitrogen management strategies to reduce nitrate leaching in tile-drained Midwestern soils. Agron. J. 94:153-171.

Eidem, J.M., W.W. Simpkins, and M.R. Burkart. 1999. Geology, groundwater flow, and water quality in the Walnut Creek watershed. J. Environ. Qual. 28:60-69.

Fuller, W.A. 1987. Measurement error models. John Wiley \& Sons, New York.

Hatfield, J.L., D.B. Jaynes, M.R. Burkart, C.A. Cambardella, T.B. Moorman, J.H. Prueger, and M.A. Smith. 1999. Water quality within the Walnut Creek watershed: Setting and farming practices. J. Environ. Qual. 28:11-24.

Hatfield, J.L., and P. Sauer. 1994. Walnut Creek watershed research protocol report. Bull. 94-1. USDA-ARS NSTL, Ames, IA. 
Jaynes, D.B., J.L. Hatfield, and D.W. Meek. 1999. Water quality in Walnut Creek watershed: Herbicides and nitrate in surface waters. J. Environ. Qual. 28:45-59.

Kempthorne, O., and R.R. Allmaras. 1986. Errors and variability of observations. p. 1-31. In A. Klute (ed.) Methods of soil analysis. Part 1. 2nd ed. Agron. Monogr. 9. ASA and SSSA, Madison, WI

Kirchner, J.W., X. Feng, and C. Neal. 2000. Fractal stream chemistry and its implications for contaminant transport in catchments. Nature (London) 403:524-527.

Lindau, C.W., W.H. Patrick, Jr., R.D. Delaune, and K.R. Reddy. 1990 Rate of accumulation and emission of $\mathrm{N}_{2}, \mathrm{~N}_{2} \mathrm{O}$, and $\mathrm{CH}_{4}$ from a flooded rice soil. Plant Soil 129:269-276.

Lowery, T.A. 1998. Modelling estuarine eutrophication in the context of hypoxia, nitrogen loadings, stratification and nutrient ratios. J. Environ. Manage. 52:289-305.

Mallin, M.A., L.B. Cahoon, D.C. Parsons, and S.H. Ensign. 2001 Effect of nitrogen and phosphorus loading on plankton in coastal plain blackwater rivers. J. Freshwater Ecol. 16:455-466.

Mann, C.J. 1987. Misuse of linear regression in the earth sciences. $p$. 74-106. In W.B. Size (ed.) Use and abuse of statistics in the earth sciences. Oxford Univ. Press, New York.

McCorvie, M.R., and C.L. Lant. 1993. Drainage district formation and the loss of Midwestern wetlands, 1850-1930. Agric. Hist. 67(4):1339.

Meek, D.W. 2001. A semiparametric method for estimating the scale of fluctuation. Comput. Geosci. 27:1243-1249.

Meek, D.W., and J.L. Hatfield. 1994. Data quality checking for single station meteorological databases. Agric. For. Meteorol. 69:85-109.

Onstad, C.A., M.R. Burkart, and G.D. Bubenzer. 1991. Agricultural research to improve water quality. J. Soil Water Conserv. 46:184188.

Pionke, H.B., W.J. Gburek, R.R. Schnabel, A.N. Sharpley, and G.F.
Elwinger. 1999. Seasonal flow, nutrient concentrations and loading patterns in stream flow draining and agricultural hill-land watershed. J. Hydrol. (Amsterdam) 220:62-73.

Pitlick, J. 1997. A regional perspective of the hydrology of the 1993 Mississippi River basin floods. Ann. Assoc. Am. Geogr. 87:135-151.

Prakash, A., R.J. Heggen, V.M. Ponce, J.A. Replogle, and H.C. Riggs. 1996. Runoff, streamflow, reservoir yield, and water quality. p. 331-437. In Hydrology handbook. 2nd ed. Am. Soc. Civil Engineers, New York.

Randall, G.W., and M.J. Gross. 2001. Nitrate losses to surface water through subsurface, tile drainage. p. 95-122. In R. Follett and J. Hatfield (ed.) Nitrogen in the environment: Sources, problems, and management. Elsevier Science Publ., Amsterdam.

Rantz, S.E. 1982. Measurement and computation of streamflow. U.S Geol. Survey Water Supply Paper 2175. U.S. Gov. Print. Office, Washington, DC.

Rodvang, S.J., and W.W. Simpkins. 2001. Agricultural contaminants in Quaternary aquitards: A review of occurrence and fate in North America. Hydrogeol. J. 9:44-59.

Ruhe, R.V. 1969. Quaternary landscapes in Iowa. Iowa State Univ. Press, Ames, IA

Sauer, T.J., R.B. Alexander, J.V. Brahana, and R.A. Smith. 2001. The importance and role of watersheds in the transport of nitrogen. p. 147-181. In R. Follett and J. Hatfield (ed.) Nitrogen in the environment: Sources, problems, and management. Elsevier Science Publ., Amsterdam.

Soil Survey Staff. 1994. Keys to soil taxonomy. 6th ed. USDA Soil Conservation Serv., Washington, DC.

Vanmarcke, E. 1983. Random fields: Analysis and synthesis. MIT Press, Cambridge, MA.

Xue, Y., D.A. Kovacic, M.B. David, L.E. Gentry, R.L. Mulvaney, and C.W. Lindau. 1999. In situ measurements of denitrification in constructed wetlands. J. Environ. Qual. 28:263-269. 